\title{
Knowledge Graph of China's Executive Compensation Gap: Visual Analysis Based on CiteSpace
}

\author{
Qingqing Peng* \\ Beijing Wuzi University; Beijing 101149, China \\ *Corresponding author: Qingqing Peng, 1808557182@qq.com
}

\begin{abstract}
This study selected 473 local research articles on executive compensation from core journals in the China Academic Journals (CNKI) full-text database and the Chinese Social Sciences Citation Index (CSSCI) from 2003 to 2020. Then, the bibliometric analysis method was adopted and conducted in regard to the number of articles published, authors, research institutions, high-frequency keywords, etc. In view of the increasing studies of this field, this study showed that a few scholars and institutions with high academic influence have been involved in the research on executive compensation gap in China. The results from this study revealed that the research on the relationship between executive compensation gap and firm performance as well as the moderating variables between them were topics of interests. In the context of the increasing compensation gap which had become a global interest, the research on management power and promotion incentives have established their significance as important research frontiers.
\end{abstract}

Keywords: Executives-employee compensation gap; Executive external compensation gap; Managerial power; Promotion incentive

Publication date: June 2021; Online publication: June 30, 2021

\section{Introduction}

On July 23, 2019, Deloitte's Executive Compensation Research Center released an investigative report on executive compensation and long-term incentives of China's A-shares listed companies from 2018 to 2019. The data were derived from Wind database, disclosed annual reports, prospectuses, and other public information of A-shares listed companies with a total of 3,607 valid samples. According to these statistics, the salary gap coefficient between executives and employees in the industry was 9.47 times which means that the salary of highest paid executives was 9.47 times of the average salary of employees in the enterprise. In regard to that, the coefficient was 7.17 times in 2017 and 7.89 times in 2016 which indicated the widening pay gap between executives and employees. Becoming a global interest, this issue had gained massive attention from the media and public. ${ }^{[1]}$ Therefore, in order to explore the influencing factors of the widening executive pay gap on its governance, this study excavates the theme and frontier trends of current existing research on executive pay gap via visualization and quantitative analysis. Necessary reflections and inventory were also conducted in regard to these research.

\section{Data Source and Research Methods}

\subsection{Data source}

The literature visualization data in this paper were from the CNKI academic journal database. In the database search, "executive pay gap" was the main keyword used, the logical relationship formula was "or", 
the source categories were "core journals" and "CSSCI" source journals, the source time was up to April 30, 2020, and the retrieval condition was "accurate". A total of 485 literatures were retrieved. However, in order to ensure the integrity and accuracy of the data, 12 literatures with either incomplete data information or irrelevant ones were eliminated manually, thereby obtaining 473 valid literatures.

\subsection{Research methods}

CiteSpace 5.6.R1 was used in this paper as a visual analysis tool in investigating the executive pay gap. This software was used for bibliometric analysis which involved a variety of parameter settings. The time span of this study was 18 years (2003 - 2020) and the time slice was set to 1 year with a total of 20 time partitions.

\section{Statistical Analysis on the Basic Characteristics of Literatures}

\subsection{Chronological distribution of literatures}

Figure 1 shows the chronological distribution of 473 sample literatures. From the results, there was an overall increase in the numbers of published research literatures on executive pay gap throughout the years. The research on executive pay gap in China could be divided into two stages. The first stage which was from 2003 to 2012 had minimal numbers of published papers but the increment was relatively stable. The second stage, from the year 2013 to 2020 not only had a significant increase in regard to the numbers of published papers but also showed a continuous upward trend. It is understood that the research nodes in this field were related to the executive compensation control policies of Chinese enterprises.

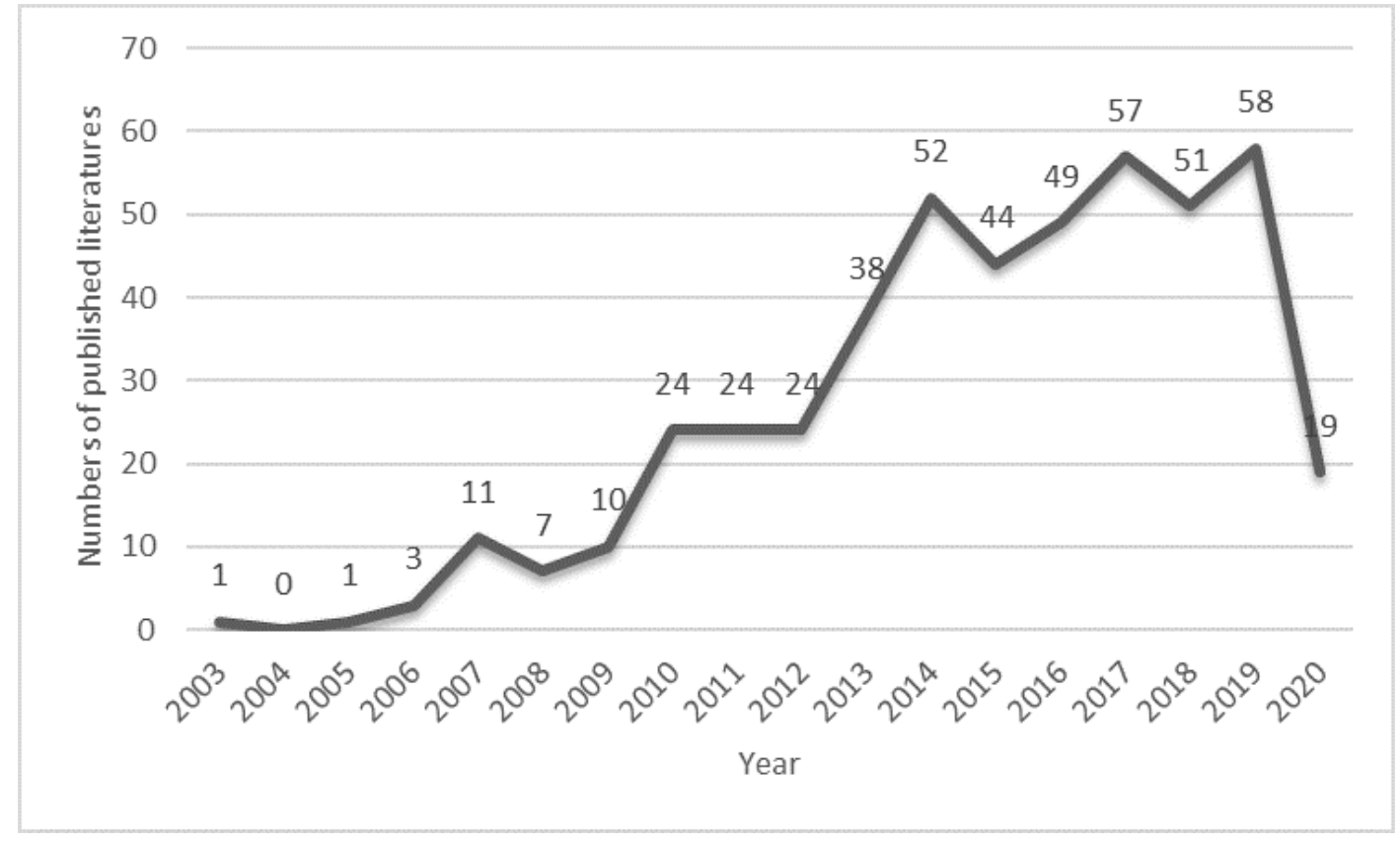

Note: Literatures in 2020 only included those up to mid-April 2020

Figure 1. Chronological distribution of the numbers of papers published in regard to the research on executive pay gap in China (2003 - 2020)

\subsection{Analysis of authors and institutions}

According to the statistics, the universities involved in Project 985 and Project 211 were the main research forces in the study on executive pay gap in China. However, the results of visualization analysis showed that the academic links among the universities were not close and the number of cooperative publications 
among them were sparse. Its' implication was that the research on executive pay gap in China were not conducted based on a matured academic community of discipline research which would have been conducive for in-depth research on executive pay gap.

\section{Knowledge Graph of Executive Compensation Research}

Keywords are terms that express the concepts of the subject in literatures. A collection of keywords from a large number of academic research achievements of a long standing domain in the academic research field would reveal the overall content characteristics of the research results, the internal relations among the research contents, the development and direction of academic research, etc. ${ }^{[2]}$ Therefore, this study used literatures as samples to conduct the analysis of keyword co-occurrence map. In this way, important research topics and academic frontiers could be explored by using burst detection algorithm.

\subsection{Exploring research topics with keyword co-occurrence map}

The research on executive pay gap in China mainly focused on pay gap, corporate performance, executive pay gap, tournament theory, and so on.

\subsubsection{Research on the relationship between executive pay gap and firm performance}

Based on the tournament theory, a few scholars suggested that executive pay gap have positive impacts on firm performance. On the other hand, other scholars suggested that having pay gaps within the top management team have negative impacts on corporate performances, and the nature of state-owned enterprises would enhance these impacts. ${ }^{[5]}$ Yet, other scholars suggested that the relationship between the internal and external pay gaps with corporate performance represents an inverted U-shaped in which the widening of the pay gap would lead to an increase in performance and later on, a decline ${ }^{[6,7]}$ In performance promotion, tournament theory would play a dominant role while in the stage of performance decline, behavioral theory holds the leading role. This is because the incentive effect of the pay gap has a marginal diminishing effect. ${ }^{[8]}$

\subsubsection{Study of moderating variables}

The inverted U-shaped relationship between executive pay gap and firm performance has attracted the attention of many scholars; hence, moderating variables which have roles in regulation have also gradually shifted into the field of study such as the property rights and the nature of the firm, the competitive intensity as well as the market environment of the industry, and so on. ${ }^{[9,10]}$ In addition to that, some scholars have also verified the inhibiting effect. For example, managerial power may inhibit the promotion between the two. ${ }^{[1]}$ Other than that, the property rights, nature, and the location of the firm would shift the critical point on the inverted U-shaped relationship to the right. ${ }^{[12]}$

\subsection{Exploring the academic frontier with burst detection algorithm}

Burst terms are keywords in which the contribution of word frequency abruptly increases over different periods of time. The greater the emergence of these terms, the more prominent the academic attention towards the keywords. Therefore, by tracking the changes in burst terms, the shifting trends of the topic in this research field in regard to different time periods can be identified. In this study, there were three burst terms related to the research field of executive compensation gap in China which were "senior management team," "management rights," and "promotion incentive." Via the analysis of keyword co-occurrence map, the academic frontier trend in the research on executive pay gap in China was represented in three phases. 
The first phase which was from the year 2007 to 2013, the burst term was "executive team." The research in this period focused on the relationship between the pay gap within the top management team and corporate performance. ${ }^{[13]}$

The second phase which was from 2014 to 2016, the burst term was "management power." Management power is an important factor that affects the executive compensation gap by aggravating the pay gap among executive-employee and the executive external. ${ }^{[14,15]}$ Many scholars have held on to the principle in which managerial power has negative effects. For example, Lu Rui and Chen Deqiu suggested that enterprises with high management power have larger pay gaps within the top management team as well as between core executives and their employees; however, the enterprise performance is the same. In addition, the existence of management power intensifies earnings management behaviors and undermines or even inhibits the incentive effect of the internal and external compensation gap of top management teams. ${ }^{[16-19]}$

The third phase which was from the year 2016 to 2018 in which the burst term was "promotion incentive." The incentive effect of executive pay gap has relations to the law of diminishing marginal benefit, so scholars turned to seek other executive incentive models. Many scholars have confirmed the positive impact of executive promotion incentives. Through empirical analysis, Zhang Honghui suggested that promotion incentives may improve the level of risk-taking among enterprises, ${ }^{[20]}$ reduce the number of corporate financial frauds, ${ }^{[21]}$ improve the quality of internal control, ${ }^{[22]}$ and promote investments by stateowned enterprises. ${ }^{[23]}$ On the other hand, promotion incentives have no effect on enterprises performance and the relationship between executive promotion incentives with research and development (R\&D) investments has significant negative correlation. ${ }^{[25]}$

\section{Conclusions and Prospects}

In order to promote and develop the research on executive pay gap in the future, the emphasis should be on management power constraints, the correlation between executives' pay and corporate performances, as well as the replacement of executive incentives. These would benefit in the establishment of theoretical systems and practical models in the research on executive pay gap.

\section{Disclosure statement}

The author declares no conflict of interest.

\section{References}

[1] Zhao Q, Wang Y, 2019, World Economy. 42(07): 94-119.

[2] Li W, Yang, 2005, Motherland. Journal of Information Science, (01): 68-70, 143.

[3] Gao Z, Wang C, 2018, Analysis of biomechanical changes and characteristics in running process based on knowledge graph. Chinese Journal of Tissue Engineering Research, 22(36): 5879-5888.

[4] Chen Y, Zhou T, 2016, Visualization analysis of domestic network public opinion governance research: based on scientific knowledge graph. Information Science, 34(11): 101-106.

[5] Zhang X, Zhu JW, 2015, Interaction between pay gap and firm performance in listed companies: based on panel data analysis of electronic communication industry. Accounting Communications, (36): 53$56,129$.

[6] Lu H, 2009, Research on executive compensation gap and firm performance from the perspective of endogenous. Soft Science, 23(12): 22-29. 
[7] Shi Y, Yang H, 2013, An empirical study on the impact of internal and external compensation gap on the future performance of top management teams. Economic Journal, (01): 104-108.

[8] Gao L, Lu J, 2015, Research on the asymmetric incentive effect of internal pay gap: a threshold panel model based on the data of manufacturing enterprises. China Industrial Economics, (08): 114-129.

[9] Lv J, 2014, Heterogeneous firms, pay gap and firm performance. Journal of Finance and Economics, (01): 71-79.

[10] Li C, Gao Y, Yu H, 2013, The impact of internal income gap on corporate performance: an empirical analysis based on the annual data of listed companies in 2013. Inner Mongolia Social Sciences, 36(06): 97-103.

[11] 2015, The relationship between internal and external executive pay gap and firm performance: an empirical study. Enterprise Economics, (04): 127-130.

[12] Wei G, Li K, 2014, An empirical study on the relationship between executive-employee pay gap and business performance in listed companies. Corporate Economics, (03): 51-55.

[13] 2010, A study on the relationship between salary gap and performance in top management teams. Population and Economics, (S1): 49-50.

[14] Li Y, Liao Q, 2015, Management power, firm performance, and pay gap: based on the data of stateowned listed companies. Accounting Communications, (21): 57-60.

[15] Liu B, Zhou W, Zhang H, 2016, High salary does not necessarily improve honesty - based on the perspective of power alienation. China's Economic Issues, (06): 82-95.

[16] Yang Z, Wang H, 2014, Internal pay gap, ownership concentration and earnings management behaviors: a comparative analysis of compensation within executive team and between executive and employee. Accounting Research, (06): 57-65, 97.

[17] 2014, Managerial power, executive human capital incentives, and firm performance. Financial Theory \& Practice, 35(06): 96-102.

[18] Li W, Cen Y, Hu Y, 2014, An empirical study on the management market and property rights of listed companies in China. Nankai Management Review, 17(04): 24-35.

[19] 2015, The relationship between internal and external executive pay gap and firm performance: an empirical study. Enterprise Economics, (04): 127-130.

[20] Zhang H, Zhang L, 2016, Property rights difference, promotion incentive and enterprise risk taking. Economic Management, 38(05): 110-121.

[21] Zhang H, Zhang L, 2017, Executive promotion incentive and financial fraud - empirical evidence from listed companies. Economic Management, 39(04): 176-194.

[22] Zhang H, Zhang L, 2018, Executive promotion, incentive direction and internal control quality. China Certified Public Accountants, (02): 52-57.

[23] Zhang H, Wang J, Miao L, 2017, A study on the relationship between promotion incentive and salary incentive and overinvestment of institute-owned enterprises. Business Research, (06): 131-136.

[24] Kang H, Hu W, Wu Z, et al., 2016,. Research Management Journal, 37(10): 51-59.

[25] Li Z, 2017, Executive motivation and firm performance: the mediating effect of R\&D investment. Accounting Bulletin, (35): 31-36, 129. 